\title{
Analysis of the Influence Factors of Hong Kong RMB Offshore Market on Speculative Capital Flows in China
}

\author{
Su Yihong \\ Department of Finance \\ Fuzhou University of International Studies and Trade \\ Fuzhou, China
}

\author{
Lin Qiubin \\ Department of Finance \\ Fuzhou University of International Studies and Trade \\ Fuzhou, China
}

\begin{abstract}
Based on the RMB offshore market in Hong Kong, this paper selects the quarterly data from 2009 to 2015 to analyze the factors that influence the speculative capital flows in China. The balance of RMB deposits in Hong Kong has a significant impact on the speculative capital flow in China, and the impact of interest rate differentials and RMB cross-border trade settlement should not be ignored. Based on the empirical conclusions, this paper proposes that we should continue to deepen the reform of interest rate liberation, actively promote the reform of onshore RMB exchange rate formation mechanism, strengthen the supervision of cross-border capital flow in Hong Kong and strengthen international cooperation and experience.
\end{abstract}

Keywords-Hong Kong RMB offshore market; Foreign speculative funds; The offshore interest rate; The offshore RMB exchange rate

\section{INTRODUCTION}

Hong Kong RMB offshore market; foreign speculative funds; the offshore interest rate; the International short-term capital refers to for the purpose of speculation, arbitrage, hedge plan change or reverse direction of flow of capital in the short term, the speculative strong capital is often referred to as "hot money". There has been a significant spread between the offshore RMB market in Hong Kong and the onshore RMB market, which provides arbitrage opportunities between the offshore and the onshore markets. Since July 2009, when cross-border trade in RMB settlement has been piloted, RMB cross-border transactions tend to be facilitated, and international hot money flows in and out through various channels. And Hong Kong serves as the main platform for RMB cross-border trade settlement. The phenomenon of arbitrage between offshore and onshore markets has been promoted on a large scale. International hot capital transactions tend to bring huge cross-border capital flows, which have a great impact on the operation of the real economy and the stability of the macro economy. Therefore, it is of great theoretical and practical significance to explore the influence of the RMB offshore market on China's international hot money from the qualitative and quantitative perspective.
Reference to the various factors affecting international capital flow theory, this paper is based on the offshore RMB market in Hong Kong, focuses on the difference in the interest rates and the $\mathrm{RMB}$ exchange rate [1]. Such factors as the settlement amount of RMB for cross-border trade and the balance of RMB deposits in Hong Kong provide a theoretical basis for the following construction of measurement model to quantitatively study the impact of offshore RMB market in Hong Kong on China's international hot money and put forward corresponding countermeasures and suggestions.

\section{MODEL}

Since July 2009, the RMB cross-border trade settlement has been implemented. Considering the availability and adequacy of the sample data, the sample interval of this paper is the quarterly data from September 2009 to December 2015. The selection of variables and the source of the data are as follows:

\section{A. Selection of dependent variable}

This paper, referring to the study of Liu Liya (2008) [2], uses the formula of overseas speculative funds: excess trade surplus excess frequent transfer error and omissions to measure the flow of China's international hot money. This is the dependent variable. This formula estimates international hot money from both illegal and legal sources: the flow of money through illegal channels does not provide accurate statistics, but it can be represented by the errors and omissions in the balance of payments. The inflow of funds through legal channels can be calculated by means of the relevant caliber in the balance of payments account. All the relevant raw data are derived from the balance of payments account. 


\section{B. Selection of independent variables}

Interest rate difference (DIR): the relative difference in interest rate levels in different regions is an important factor affecting speculative capital flows, usually from low interest rates to high interest rate areas [3]. If the other influencing factors are unchanged, the higher the interest rate difference, the larger the speculative capital flows with the purpose of arbitrage, and the two are positively correlated. In this case, the domestic interest rate chooses SHIBOR, the Hong Kong interest rate selects HIBOR, and the difference between the onshore interest rate and the offshore rate is: $\mathrm{DIR}=\mathrm{SHIBOR} / \mathrm{HIBOR}$. The SHIBOR data comes from the Shanghai interbank offered rate official website, and the HIBOR data comes from the financial data monthly published by the Hong Kong monetary authority's website, which takes the end value of each quarter.

RMB spot price difference (NIR). CNY divided by $\mathrm{CNH}$ indicates the difference in the spot price of RMB, namely $\mathrm{NIR}=\mathrm{CNY} / \mathrm{CNH} . \mathrm{CNY}$ data are obtained from the official website of the State Administration of Foreign Exchange (SAFE) and CNH comes from the HKMA website.

RMB cross-border trade settlement (T) and Hong Kong's RMB deposit balance (S). Take the monthly data from the HKMA website.

\section{Equations}

Accordingly, the econometric model equation is as follows:

$$
\mathrm{Ct}=\alpha 0+\alpha 1 \mathrm{DIRt}+\alpha 2 \mathrm{NIRt}+\alpha 3 \mathrm{Tt}+\alpha 4 \mathrm{St}+\varepsilon \mathrm{t}
$$

Based on this model, this paper makes an empirical study on the factors influencing the flow of speculative funds in China from the Hong Kong RMB offshore market.

\section{EMPERICAL TEST}

\section{A. Empirical process}

Theoretically, because of the interest rate difference between the onshore market, the exchange difference and the convenience provided by the cross-border RMB trade settlement house, the flow of China's international hot money will be increased.

The following is a selection of quarterly data from September 2009 to December 2015, using SPSS statistical software to carry out OLS regression to further verify whether the effect exists, and the results are as follows.

offshore RMB exchange rate

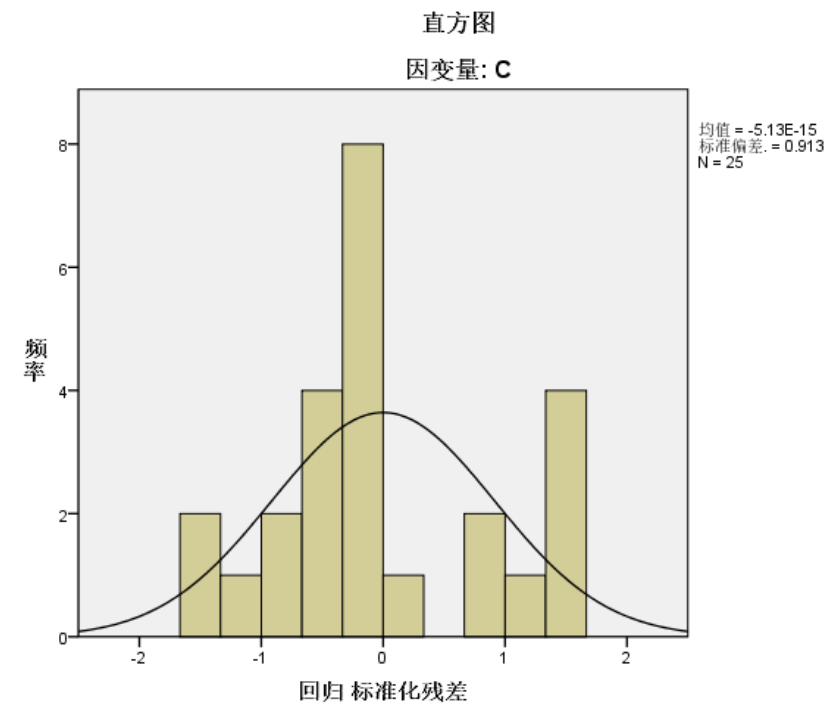

Fig. 1. Regression standardization of residual histogram

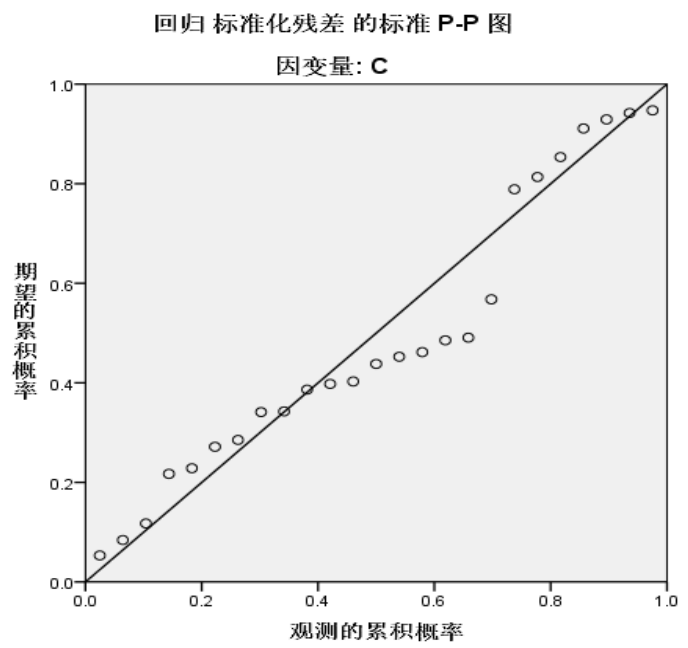

Fig. 2. Return to normalized normal probability graph

It can be seen from the standardized residual histogram and p-p graph that the residual difference of the regression equation is basically satisfied with the normal distribution, which is basically consistent with the condition of linear regression. 
TABLE I. MODEL SUMMARY

\begin{tabular}{|c|c|c|c|c|c|}
\hline Model & $\mathrm{R}$ & $\mathrm{R}$ square & $\begin{array}{c}\text { Adjus-ting R } \\
\text { square }\end{array}$ & $\begin{array}{c}\text { Standard estimation } \\
\text { error }\end{array}$ & Durbin-Watson \\
\hline 1 & .632 & .399 & .279 & 922.472438887423 & 1.978 \\
\hline
\end{tabular}

TABLE II. VARIANCE ANALYSIS

\begin{tabular}{|r|r|r|r|r|r|r|}
\hline \multicolumn{2}{|r|}{ Model } & quadratic sum & df & mean square & F & Sig. \\
\hline \multirow{2}{*}{1} & Regress-ion & 11310659.39 & 4 & 2827664.84 & 3.32 & .031 \\
\cline { 2 - 8 } & residual & 17019108.01 & 20 & 850955.4 & & \\
\cline { 2 - 7 } & sum & 28329767.40 & 24 & & & \\
\hline
\end{tabular}

TABLE III. COEFFICIENT

\begin{tabular}{|c|c|c|c|c|c|c|c|c|}
\hline & \multirow{2}{*}{ Model } & \multicolumn{2}{|c|}{ Non-standardized coefficient } & \multirow{2}{*}{$\begin{array}{r}\begin{array}{r}\text { Standardized } \\
\text { coeffici-ent }\end{array} \\
\text { Beta }\end{array}$} & \multirow{2}{*}{$\mathrm{t}$} & \multirow{2}{*}{ Sig. } & \multicolumn{2}{|c|}{ Collinear statistics } \\
\hline & & $\mathrm{B}$ & standard error & & & & toler-ance & VIF \\
\hline \multirow{5}{*}{1} & $\mathrm{C}$ & -51951.494 & 18976.216 & & -2.738 & .013 & & \\
\hline & $\mathrm{S}$ & -1.069 & .438 & -2.953 & -2.44 & .024 & .021 & 48.75 \\
\hline & $\mathrm{T}$ & .612 & .361 & 1.328 & 1.695 & .106 & .049 & 20.43 \\
\hline & NIR & 63681.153 & 21463.478 & 1.864 & 2.967 & .008 & .076 & 13.14 \\
\hline & DIR & 441.67 & 248.73 & .505 & 1.776 & .091 & .371 & 2.697 \\
\hline
\end{tabular}

\section{B. The Process of Measurement result}

Table 1 shows that the DW value is 1.978 , close to 2 , indicating that the residuals are independent and there is no sequence autocorrelation. According to table 2, the significant level of the model is $0.031<0.05$, which passed the F test. In addition, it can be seen from table 3 that the tolerance of each variable in the equation is not very small, and the VIF is not very large, which excludes the possibility of multiple collinearity.

Regression equation of a single variable in addition to $\mathrm{LN} \mathrm{t}$ value more than 0.1 significance level, didn't pass the test, the other variables through the test, but the significance level of DIR is more than 0.05 , the significance is not strong. The significance of other variables are less than 0.05 , which is very significant and the sign of the variables is in accordance with the expectation.

The standardized coefficient of the DIR is 0.505 , compared with other factors its influence on dependent variable $\mathrm{C}$ is relatively small and the significance of the test is not very high. However, no matter what theory explains cross-border capital flows, it can not deny the influence of interest rate differentials. Why from onshore spreads explanatory power is not strong, the main reasons are as follows: first, China's capital account has not been fully liberalized, capital account is under government control, and a large number of capital flows are restricted; Second, the formula used above to calculate the scale of overseas speculative funds cannot fully reflect the cross-border capital flow of arbitrage based on the method of false trade and black market trading. Therefore, we can not deny the impact of spreads on international flows of hot money.
As can be seen from the standardized coefficients of various influencing factors, the exchange rate has the strongest explanatory power for the international capital flow of China. It can be seen that the current exchange rate of RMB exchange between the onshore market is the main reason to promote the cross-border flows.

The reason why the RMB cross-border trade settlement has failed the test is that Hong Kong's official statistics may not be able to eliminate the false trade elements contained therein, at the same time it's not easy to cover involved in smuggling, illegal channels such as underground banks.

From the coefficient of RMB cross-border trade settlement, it can be seen that the cross-border trade in the onshore market is positively correlated with the flow of international capital flows, which is consistent with the previous analysis. It is certain that the analysis of the impact of RMB cross-border trade settlement on the RMB offshore market in Hong Kong is established.

The balance of RMB deposits in Hong Kong is also one of the factors that affect the flow of international capital flows in China, and its standardized coefficient is -2.953 , which is negative. This indicates that the decrease of RMB deposit balance in Hong Kong will bring about the inflow of international hot money in China.

In general, the fitting degree of the model is 0.399 , indicating that its overall explanatory ability is low, and there are other factors that influence the flow of international hot money in China. 
To this, this paper is as follows: on the one hand, since the exchange rate is a significant factor and our country is implementing a managed floating exchange rate system, the expectation of RMB exchange rate appreciation should be included in the influencing factors; On the other hand, the official launch of the Shanghai-Hong Kong stock connect and Shenzhen stock connect has realized the two-way opening of the mainland and Hong Kong stock markets, and the stock market return from the onshore market should also be a factor.

More in-depth analysis is needed.

\section{CONCLUSIONS AND SUGGESTIONS}

According to the result of the above empirical analysis, we can draw a conclusion that the main factors influencing China's international floating capital flow in the Hong Kong offshore RMB market are interest rate difference, exchange rate difference, RMB cross-border trade settlement and Hong Kong RMB deposit balance. The speculative nature of international hot money determines its highly unstable volatility. This may seriously affect the macroeconomic regulation and control effect of central banks, and is not conducive to the stable development of the economy. Therefore, this paper puts forward the following countermeasures and suggestions. First, we should continue to deepen the reform of marketization of interest rates, perfect various supporting environments, form a market-led onshore interest rate price system, and narrow the spread of interest rates in order to weaken the arbitrage motive of cross-border speculative capital inflows. Second, it is necessary to actively promote and improve the reform of the onshore RMB exchange rate formation mechanism, enhance the flexibility of the RMB exchange rate floating in both directions, and keep the RMB exchange rate basically stable at a reasonable equilibrium level [4]. This will help curb the scale of international floating capital flows. It is necessary to mitigate the impact of international floating capital on onshore economy.
Furthermore, we should strengthen the supervision of crossborder capital flows in Hong Kong, as soon as possible perfect channel monitoring, early warning and management mechanism, and strengthen the contact with the Hong Kong monetary authority. Set up the mechanism of information exchange and sharing, and to strengthen the construction of credit system, increase of underground banks and illegal foreign exchange, in order to improve the risk prevention capabilities [5]. Finally, it is necessary to strengthen international cooperation and experience for reference, and the central bank should strengthen cooperation with the Hong Kong regulatory authorities and governments of various countries to coordinate policies on cross-border speculative capital flows [6]. At the same time, the information provided by relevant international organizations, such as the International Monetary Fund and the World Bank, should be fully utilized to establish information-sharing with regulatory authorities in other countries in order to absorb the beneficial practices and successful experiences of these countries in regulating the offshore market.

\section{REFERENCES}

[1] Zhang Yihao, Peiping and Fang Xianming (2007). China 's short-term international capital inflow and its motivation-Empirical research on the triple arbitrage model based on interest rate, exchange rate and price. International [J]. Financial Research, (9): 41 - 52. (In Chinese)

[2] Liu Liya (2008). Did the foreign "hot money" push up the stock market and the housing market? -Evidence from the Chinese market [J].Financial Research, (10): 48-70. (In Chinese)

[3] Garbe (2011). The Council on Foreign Relations \& China Development Research Foundation Workshop on the Internationalization of the RMB [A]. What Currently Drives CNH Market Equilibrium[C]. Beijing:2011$10-31$

[4] Zhang Ming, He Fan (2012). Research on offshore arbitrage in the process of $\mathrm{RMB}$ internationalization. [J]. International Financial Research, ( 10 ): 47-54.(In Chinese)

[5] Zhang Bin, Xu Qiyuan (2012). RMB internationalization under the Control of Exchange rate and Capital account $[\mathrm{J}]$.International Economic Review.(In Chinese)

[6] Pei Changhong (2015). Discussion on financial reform in China free trade test area [J]. International trade, (7):4-8. (In Chinese) 